\title{
Concrete with Improved Chloride Binding and Chloride Resistivity by Blended Cements
}

\author{
Katalin Kopecskó ${ }^{1}$ and György L. Balázs ${ }^{2}$ \\ ${ }^{1}$ Department of Engineering Geology and Geotechnics, Budapest University of Technology, Muegyetem Rkp. 3, Budapest 1111, Hungary \\ ${ }^{2}$ Department of Construction Materials and Technologies, Budapest University of Technology, Muegyetem Rkp. 3, \\ Budapest 1111, Hungary
}

Correspondence should be addressed to György L. Balázs; balazs.gyorgy@epito.bme.hu

Received 6 April 2017; Revised 2 July 2017; Accepted 12 July 2017; Published 29 August 2017

Academic Editor: Frederic Dumur

Copyright @ 2017 Katalin Kopecskó and György L. Balázs. This is an open access article distributed under the Creative Commons Attribution License, which permits unrestricted use, distribution, and reproduction in any medium, provided the original work is properly cited.

\begin{abstract}
Durability and service life of concrete structures can be endangered by chloride ions. Two phenomena help to keep control of chloride effects. On one hand cements are able to bind chloride ions by their aluminate clinker phases or by the clinker substituting materials. On the other hand resistivity of concrete against chloride penetration can be improved by careful selection of concrete constituents and production. Detailed results of two series of extensive experimental studies are presented herein. Chloride ion binding capacity of tested cements in decreasing sequence was the following: (1) CEM III/B 32,5 N-S; (2) CEM III/A 32,5 N; (3) CEM II/B 32,5 R; (4) CEM II/B-M (V-L) 32,5 R; (5) CEM I 42,5 N. Test results indicated that the increasing substitution of clinkers by GGBS improves the chloride resistivity in concrete made with the same water to cement ratio. The application of air entraining agent increases considerably the values of $D_{\text {nssm }}$. Based on the migration coefficients $\left(D_{\text {nssm }}\right)$ the following sequence of efficiency was found (from the best): CEM III/B 32,5 N > CEM V/A (S-V) 32,5 N > CEM III/A 32,5 N > CEM II/B-S 42,5 R > CEM II/A-S $42,5 \mathrm{~N}>$ CEM I $42,5 \mathrm{~N}$.
\end{abstract}

\section{Introduction}

One of the most important objectives of durability design is to control the penetration of chloride ions up to the level of steel reinforcement. The increase of concrete cover seems to be a possible solution. However, this should not be the optimal solution since the dead load of the structure increases by the increase of concrete cover in addition to the increased probability of spalling of concrete cover for high thicknesses. Another solution is the application of high performance concrete with low permeability and improved resistivity against chloride diffusion.

Empirical and physical prediction models are available for chloride ingress and corrosion initiation in concrete structures [1]. When chlorides penetrate through the concrete cover and reach the steel reinforcement, the corrosion will initiate when a certain chloride concentration (the threshold value) is reached [2-5]. Studies on the effects of chloride ions deal either with binding of chloride ions or with the transport processes (migration or penetration) of chloride in concrete. In order to understand the beginning and development of corrosion process of steel reinforcements, we have to understand both effects in detail [6-9]. Interaction of chloride ions and cements can be studied by testing directly the interaction of chloride ions and the clinker minerals. It is well-established that both $\mathrm{C}_{3} \mathrm{~A}$ and $\mathrm{C}_{4} \mathrm{AF}$ are able to bind chloride ions by the formation of Friedel's salt $\left(\mathrm{C}_{3} \mathrm{~A} \cdot \mathrm{CaCl}_{2} \cdot \mathrm{H}_{10}\right)$, or its iron analogue $\left(\mathrm{C}_{3} \mathrm{~F} \cdot \mathrm{CaCl}_{2} \cdot \mathrm{H}_{10}\right)$, if chlorides originated from $\mathrm{CaCl}_{2}$ are dissolved in the mixing water [10].

In the hardened cement paste two main chloride binding mechanisms are considered (i) through physical adsorption and (ii) through chemical reactions [11]. The CSH phase is considered to physically bind chlorides due to its high specific surface values [12-15]. The AFm compounds are generally known to be able to bind chloride ions through chemical substitution [12, 16-19]. When considering the chloride binding capacity of a commercial Portland cement, it is concluded in [20] that Friedel's salt is the only hydrated 
phase formed that incorporated chlorides into its structure, up to an external chloride concentration of 3 moles. This statement is in agreement with our further results [21]. Even the composition of the Portland cements could be different, because of the addition of latent hydraulic or pozzolanic components [22]. The clinker substituting constituents (slag, fly ash, and trass) are influencing the chloride binding ability. One of our previous studies indicated that hardened slag itself can also bind chloride ions. The presence of Friedel's salt was proved by XRD. Tests were carried out to study the chloride ion binding of blast furnace slag without cement clinkers (steam-cured samples for $8 \mathrm{hrs}$ at $80^{\circ} \mathrm{C}$ ). We have shown that the improved chloride ion binding capacity of the slag cements is owing to the slag content even if its hydration was not in the typical environment of cement hydration with high $\mathrm{pH}$ value [21].

Steam curing is a generally used method in the production of precast concrete elements. Increased temperature accelerates the hydration resulting in high early strength. However the accelerated curing affects detrimentally both the long-term strength and the durability. Hooton and Titherington [23] concluded that steam-cured concrete containing silica fume or blends of both silica fume and ground granulated blast furnace slag exhibit improved chloride penetration resistance compared to those of Portland cement concrete. Dhir and his coauthors [24] reported the results of chloride binding measurements of GGBS pastes, as well as chloride diffusion and permeability measurements of GGBS concrete mixes. They found that, in concrete designed to have a minimum volume of voids, the chloride ion binding capacity of the cement matrix becomes the dominant factor in how resistant the concrete is to chloride permeation. Luo and his colleges [25] experimentally studied both the chloride diffusion coefficient and the chloride binding capacity of Portland cement or blended cement made of Portland cement and $70 \mathrm{~m} \%$ GGBS replacement. They found that (i) chloride diffusion coefficient decreased and (ii) chloride ion binding capacity improved in samples of blended cement.

Nevertheless, to determine the extent of the chloride ion binding by the cements made with different amount of GGBS or other clinker substituting materials is highly important (see details in Section 2). Clinker substituting constituents are also known as supplementary cementing materials (SCMs) with latent hydraulic or pozzolanic behaviour. One of the experimental parameters was the circumstances of the hardening: both naturally hardened and accelerated hardened (steam-cured) cement paste specimens were subjected to salttreatment. The reason was to study the difference between the chloride ion binding capacities in case of cast-in situ (naturally hardened) or prefabricated concrete. Cements with increasing slag contents have improved capacity for chloride binding.

We have studied then the chloride diffusion as a function of the slag content or other substituting materials of cements as well as the presence of air entraining agents (see details Section 3). Concrete specimens were prepared by different water to cement ratios, in order to study the resistivity of concrete against chloride ions. The amount of cement was kept constant in all concrete mixtures. Test results of concrete without air entraining agents were compared to test results of concrete made with air entraining agents. Test results indicated that the increasing substitution of clinkers by GGBS improves the chloride resistivity in concrete made with the same water to cement ratio. The application of air entraining agent reduces the chloride resistivity, because the permeability increases by the increased porosity.

\section{Blended Cements for Enhanced Chloride Binding Capacity}

2.1. Purpose of Research. Purpose of this part of research was to answer the following questions: (a) what is the effect of the different amount of clinker substituting materials on the chloride ion binding of cements and (b) what is the influence of the curing temperature (natural hardening at $20^{\circ} \mathrm{C}$, or steam curing at $80^{\circ} \mathrm{C}$ ) on the hydration processes and on chloride ion binding capacities of cements? We followed the methods in [26] and the experimental observations were considerably extended.

2.2. Experimental Studies. Five types of cements were selected with different amounts of clinker substituting constituents. Sulphate contents of the standardised cement products were not modified (hence the influence of various sulphate contents of the cements was not studied). Cements involved into this comparative study were for reference CEM I 42,5 N ordinary Portland cement, two other Portland cements (CEM II/B-M (V-L) 32,5 R and CEM II/B-S 32,5 R), and two blast furnace slag cements (CEM III/A 32,5 N and CEM III/B 32,5 $\mathrm{N}-\mathrm{S})$. Cement clinkers and other main constituents different from clinkers were ground together during the production of cement. According to the standard MSZ EN 197-1:2000 [27] main constituents are specially selected inorganic materials in a proportion exceeding $5 \%$ by mass related to the sum of all main and minor additional constituents. Amount of the main constituents different from clinkers in case of cements involved in our study is summarized in Table 1. The composition of clinker minerals was the same in case of the cements as in CEM I 42,5 R ordinary Portland cement (reference). Composition of clinker minerals in ordinary Portland cements and composition of clinker minerals in the blended cements were the same. Samples of cement pastes were prepared by the required amount of water to reach the standard (semiplastic) consistence according to the Hungarian standard MSZ EN 196-3:2005 [28] (Table 1). The chemical compositions of tested cements are given in Table 2.

Tests were carried out to study the influence of steam curing and salt-treatment of cements paste specimens (Table 3 ).

The samples of series 1 and 2 were naturally hardened and after demoulding these samples were kept at room temperature $\left(22 \pm 3^{\circ} \mathrm{C}\right)$ in $100 \%$ r.h. The samples of series of 3 and 4 were steam-cured for $3 \mathrm{hrs}$ at $80^{\circ} \mathrm{C}$; then samples were kept in the same condition as series of 1 and 2 . Salt-treatment meant to keep the specimens in $10 \% \mathrm{NaCl}$ solution, between 28 and 38 days ( 24 hrs in the salt solution, followed by $24 \mathrm{hrs}$ of drying cyclically). Salt-treated samples were kept then at room temperature $\left(22 \pm 3^{\circ} \mathrm{C}\right)$ and $100 \%$ r.h. Tests of hardened samples were carried out at different ages (90 and 180 days). 
TABLE 1: Cement types involved into the study, percentages of clinker substituting constituents, and the applied water-cement ratio of standard (semiplastic) consistence.

\begin{tabular}{lcc}
\hline Cements & Type and amount of main constituents in cements & Water to cement ratio \\
\hline CEM I 42,5 N (OPC) & 0 m\% & 0.273 \\
CEM II/B-M (V-L) 32,5 R & 18 m\% V, 10 m\% L & 0.270 \\
CEM II/B-S 32,5 R & $26 \mathrm{~m} \%$ GGBS & 0.272 \\
CEM III/A 32,5 N & $40 \mathrm{~m} \%$ GGBS & 0.285 \\
CEM III/B 32,5 N-S & $62 \mathrm{~m} \%$ GGBS & 0.302 \\
\hline
\end{tabular}

Notes. V: fly ash, L: limestone powder, and GGBS: ground granulated blast furnace slag.

Hydration and chloride binding were studied by thermal test (TG/DTG/DTA) using Derivatograph Q-1500 D and Xray diffraction (XRD) using Philips PW 3710 diffractometer. Derivatograph Q-1500 D is simultaneous thermoanalytical test method where thermogravimetric (TG) and differential thermoanalytical (DTA) curves are produced during the same measurement. The 1st derivative of thermogravimetric curve (DTG) is also obtained. Reference material was alumina; heating rate was $10^{\circ} \mathrm{C} / \mathrm{min}$ up to about $1000^{\circ} \mathrm{C}$. Tests were carried out in air atmosphere. The other method was $\mathrm{X}$-ray diffraction (XRD). X-ray powder diffraction analyses were carried out by a Philips PW 3710 diffractometer. Parameter values of measurements were as follows: generator tension was $40 \mathrm{kV}$, generator current was $30 \mathrm{~mA}$, and tube anode was $\mathrm{Cu}$ (long fine focus), with monochromator. For the analysis the Total Access Diffraction Database PDF-2 (PLUS 42) software was used. Investigation of both thermoanalytical and powder X-ray diffraction measurements made it possible to carry out detailed analysis of phase modifications.

\subsection{Results and Discussion}

2.3.1. Results of XRD Analyses. X-ray patterns of salt-treated cement paste samples indicated the formation of Friedel's salt (calcium-aluminate-chloro-hydrate, $\mathrm{C}_{3} \mathrm{~A} \cdot \mathrm{CaCl}_{2} \cdot \mathrm{H}_{10}$ ). The other $\mathrm{Cl}^{-}$-containing AFm phase, Kuzel's salt $\left(\mathrm{C}_{3} \mathrm{~A} \cdot 0,5 \mathrm{CaSO}_{4}\right.$ $\left.\cdot 0,5 \mathrm{CaCl}_{2} \cdot \mathrm{H}_{12}\right)$, did not appear in the salt-treated cement paste samples $[29,30]$. This statement is in agreement with the results of Balonis et al. [20]. Figure 1 shows the XRD patterns of CEM III/A 32,5 $\mathrm{N}$ at the age of 180 days. The absolute intensity of Friedel's salt in the steam-cured sample of CEM III/A $32,5 \mathrm{~N}$ was $35 \%$ higher $\left(I_{\mathrm{abs}}=131\right.$ counts $)$ comparing with the absolute intensity of non-steam-cured sample $\left(I_{\mathrm{abs}}=97\right.$ counts $)$. Monosulphate did not appear in the non-steam-cured samples. $\mathrm{X}$-ray patterns indicated formation of monosulphate $\left(\mathrm{AFm}, \mathrm{C}_{3} \mathrm{~A} \cdot \mathrm{CaSO}_{4} \cdot \mathrm{H}_{12}\right)$ parallel to ettringite formation ( $\mathrm{AFt}, \mathrm{C}_{3} \mathrm{~A} \cdot 3 \mathrm{CaSO}_{4} \cdot \mathrm{H}_{32}$ ) in the steamcured samples. The intensity of ettringite formation was higher in the salt-treated samples compared to the samples kept without salt-treatment. This observation can be explained by the reaction of sulphate ions released from the transformation monosulphate $\rightarrow$ Friedel's salt. The reaction of sulphate ions and the aluminate-ferrite mono- (AFm-) phases lead to the secondary ettringite formation observed here. The competitive reactions of AFm phase with chloride ion or with sulphate ion were observed. Higher absolute intensity of Friedel's salt was observed in all steam-cured samples than those of non-steam-cured samples of cements.

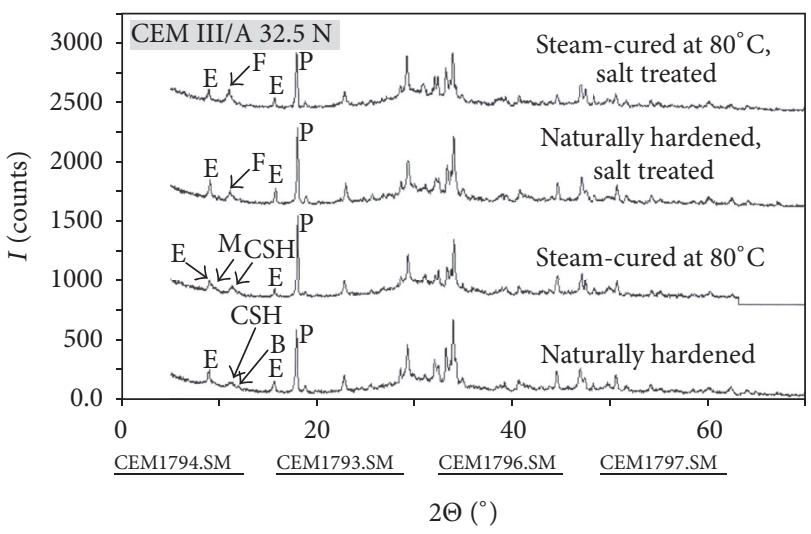

FIGURE 1: Influence of steam curing and salt-treatment on cement hydration, X-ray patterns of CEM III/A 32,5 N at the age of 180 days. Note. E: ettringite; F: Friedel's salt; M: monosulphate; P: portlandite; B: Brownmillerite; CSH: calcium-silicate-hydrate.

2.3.2. Results of TG/DTG/DTA Analyses. Figure 2 shows the first derivatives of thermogravimetric curves (DTG curves) in case of non-salt-treated (non-steam-cured, age: 90 days) and salt-treated samples steam-cured at $80^{\circ} \mathrm{C}$ at the age of 180 days. The following thermogravimetric changes were observed: (1) loss of humidity and dehydration of ettringite; (2) the second step of dehydration of Friedel's salt; (3) dehydration of portlandite; (4) decomposition of carbonates and $\mathrm{CSH}$. The most remarkable difference between the results of thermal tests of salt-treated and non-salt-treated samples is the presence of a peak of DTG at approx. $360^{\circ} \mathrm{C}$ (salttreated samples), which can be attributed to the formation of Friedel's salt ( 6 moles of $\mathrm{H}_{2} \mathrm{O}$ of the total 10 mole $\mathrm{H}_{2} \mathrm{O}$ ). $40 \%$ of the water content ( 4 moles of $\mathrm{H}_{2} \mathrm{O}$ ) of Friedel's salt is lost below $200^{\circ} \mathrm{C}$. The chemically bound chloride content was calculated from the second step of dehydration of Friedel's salt. Six moles of water represented 1 mole of Friedel's salt. The stoichiometric factor calculating the amount of Friedel's salt is $f_{\mathrm{Fs}}=5,2$. The chloride content in Friedel's salt is $12,6 \%$.

Figure 3 shows the diagram of the chemically bound chloride content of salt-treated samples related to the mass of samples without the ignition loss. Test results indicated that steam-cured cements can bind higher amount of chloride ions than naturally hardened ones. Chloride ion binding capacity of tested cements in decreasing sequence at the age of tests (90 days or 180 days) was the following: (1) CEM III/B 32,5 (blast furnace cement); (2) CEM III/A 32,5 (blast furnace cement); (3) CEM II/A 32,5 (Portland-slag cement); (4) CEM 


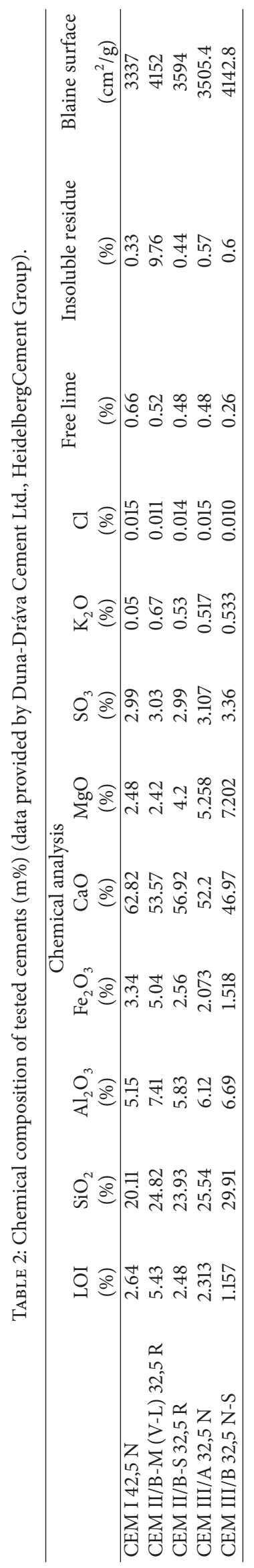


TABLE 3: Experimental programme.

\begin{tabular}{lcc}
\hline Series & Curing & Exposure \\
\hline 1 & Natural hardening at $22^{\circ} \mathrm{C}$ and $100 \%$ r.h. & - \\
2 & Natural hardening at $22^{\circ} \mathrm{C}$ and $100 \%$ r.h. & Salt-treatment \\
3 & Steam curing at $80^{\circ} \mathrm{C}$ and $100 \%$ r.h. & - \\
4 & Steam curing at $80^{\circ} \mathrm{C}$ and $100 \%$ r.h. & Salt-treatment \\
\hline
\end{tabular}

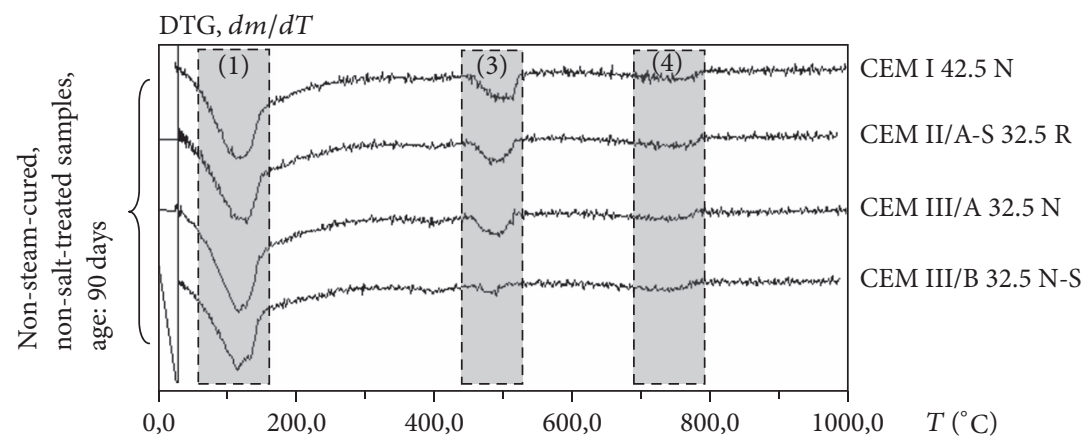

(a)

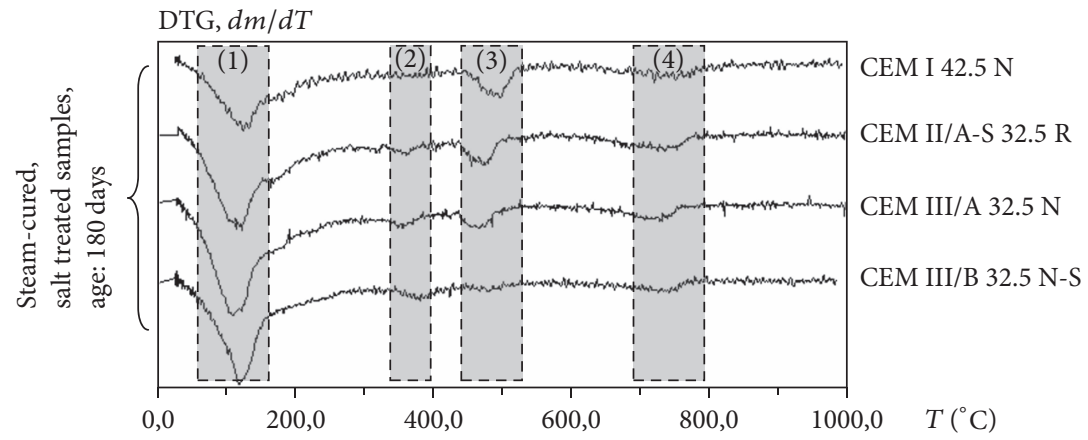

(b)

FIGURE 2: DTG curves of cement paste samples with increasing content of GGBS: (a) non-steam-cured and non-salt-treated samples at the age of 90 days; (b) steam-cured and salt-treated samples at the age of 180 days (salt-treatment: between the ages of 28-38 days). Note. (1) Loss of humidity and dehydration of ettringite; (2) the second step of dehydration of Friedel's salt; (3) dehydration of portlandite; (4) decomposition of carbonates and CSH.

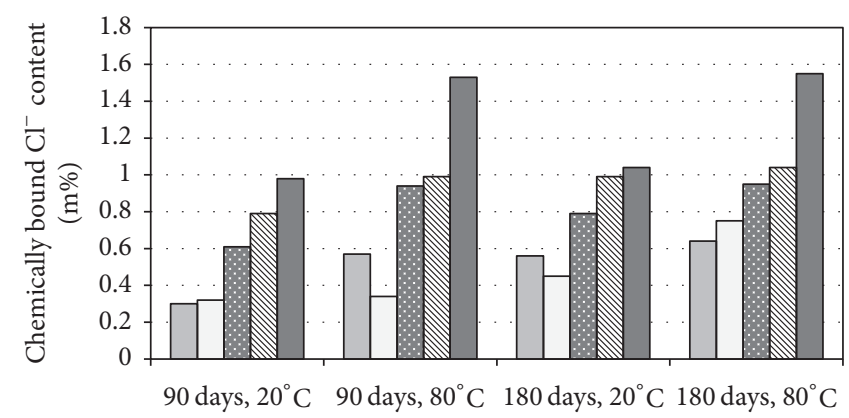

Age of samples and curing temperature

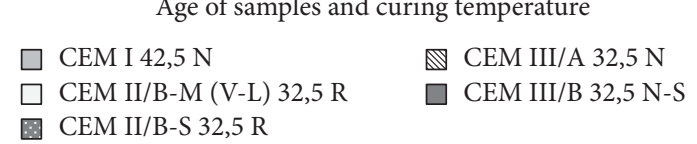

Figure 3: Amount of chemically bound $\mathrm{Cl}^{-}$ions (m\%) calculated from the second step of dehydration of Friedel's salt, related to the mass of samples without ignition loss as functions of ages and type of curing (cement paste samples were naturally hardened or steam-cured at $80^{\circ} \mathrm{C}$ ). 
TABLE 4: Standard composition of the tested cements according to EN 197-1:2000, m\%.

\begin{tabular}{|c|c|c|c|c|}
\hline \multirow{3}{*}{ Cement types } & \multicolumn{4}{|c|}{ Constituents in standard composition of the tested cements, $\mathrm{m} \%$} \\
\hline & \multicolumn{3}{|c|}{ Main } & \multirow{2}{*}{$\begin{array}{l}\text { Minor } \\
\text { Gypsum }\end{array}$} \\
\hline & Clinkers & GGBS & Fly ash & \\
\hline CEM I $42,5 \mathrm{~N}$ & $95-100$ & 0 & 0 & 5 \\
\hline CEM II/A-S 42,5 N & $85-94$ & $15(6-20)$ & 0 & 5 \\
\hline CEM II/B-S 42,5 R & $65-79$ & $20(21-35)$ & 0 & 5 \\
\hline CEM III/A 32,5 N & $35-64$ & $60(36-65)$ & 0 & 5 \\
\hline CEM III/B 32,5 N-S & $20-34$ & $75(66-80)$ & 0 & 5 \\
\hline CEM V/A (S-V) $32,5 \mathrm{~N}$ & $40-64$ & $30(18-30)$ & $30(18-30)$ & 5 \\
\hline
\end{tabular}

II/B-M (V-L) 32,5 (Portland composite cement); (5) CEM I 42,5 (ordinary Portland cement).

In a previous study the chemically bound chloride content was calculated by indirect way from the total and water soluble chloride content. Both the total and water soluble chloride content were measured with analytical methods [29]. They found that blast furnace slag cement pastes have higher chloride ion binding capacity compared with the Portland cement control. This conclusion is in accordance with our test results obtained from the thermogravimetric mass loss of the second dehydration step of Friedel's salt using the thermogravimetric (TG) and derivative thermogravimetric (DTG) curves of thermal tests.

\subsection{Summary of Observations for Chloride Binding Capacity.} Purpose of this part of research was to study the effect of clinker substituting constituents (supplementary materials) and the influence of steam curing on chloride ion binding capacity of cements. Hydration as well as chloride ion binding mechanisms was investigated by TG/DTG/DTA and XRD. Five types of cements were selected with different amount of clinker substituting constituents. Salt-treatment of paste specimens was done between the ages of 28 and 38 days. Test results indicated that steam curing enhances the chloride binding capacity of cement paste samples comparing with the naturally hardened ones. Chloride ion binding capacity of tested cements in decreasing sequence at the age of 180 days was the following: (1) CEM III/B 32,5 N-S (with $62 \mathrm{~m} \%$ GGBS); (2) CEM III/A 32,5 N (with 40 m\% GGBS); (3) CEM II/B 32,5 R (with 26 m\% GGBS); (4) CEM II/B-M (V-L) 32,5 $\mathrm{R}$ (with $18 \mathrm{~m} \% \mathrm{~V}+10 \mathrm{~m} \% \mathrm{~L}$ ); (5) CEM I 42,5 N (ordinary Portland cement, reference). The chemically bound chloride content increased with the increasing GGBS replacement level in case of slag cements. It was also experimentally shown that in the same type of cement (CEM II/B) the addition of ground granulated blast furnace slag (in Portland-slag cement, CEM II/B 32,5 R) is more effective in chloride ion binding as the fly ash and limestone in Portland composite cement (CEM II/B-M (V-L) 32,5 R). Limestone acts as an inert material for chloride binding.

\section{Blended Cements for Enhanced Chloride Resistivity}

3.1. Purpose of the Study. In this series of experiments different types of blended cements were used to study the influence of the clinker substituting constituents on chloride resistivity. The test variables were (i) types of cements, (ii) the water to cement ratios; (iii) presence or absence of air entraining agent. Another purpose was to study the influence of air entraining agent which can change the permeability of concrete. The test parameters were (i) the cement content in concrete mixtures $\left(440 \mathrm{~kg} / \mathrm{m}^{3}\right)$ and (ii) consistency of fresh concrete mixtures, while the studied characteristics were non-steady-state migration coefficients $\left(D_{\text {nssm }}\right)$.

\subsection{Experimental Studies}

3.2.1. Tested Cement Types. In this study three Portland cements, two blast furnace cements, and one composite cement were selected with different amounts of GGBS (ground granulated blast furnace slag) (Table 4). Cements involved in our experiments are as follows: ordinary Portland cement (CEM I 42,5 N: reference cement), Portland-slag cements (CEM II/A-S 42,5 N, CEM II/B-S 42,5 R), blast furnace cements (CEM III/A-S 32,5 N, CEM III/B-S 32,5 N), and composite cement (CEM V/A (S-V) 32,5 N). In CEM $\mathrm{V} / \mathrm{A}(\mathrm{S}-\mathrm{V}) 32,5 \mathrm{~N}$ composite cement the main constituents are GGBS and fly ash. According to the standard MSZ EN 1971:2000 [35] main constituents are specially selected inorganic materials in a proportion exceeding $5 \%$ by mass related to the sum of all main and minor additional constituents. Amount of the main constituents different from clinkers in case of the cements involved in our study is summarized in Table 4. The composition of clinker minerals was the same in all types of cements as in CEM I 42,5 N ordinary Portland cement. All of the tested cements were standardised products of DunaDráva Cement Hungary Ltd. (HeidelbergCement Group). The chemical compositions of tested cements are given in the Table 5 .

3.2.2. Concrete Mixtures. The amount of cement in the different concrete mixtures was the same $\left(440 \mathrm{~kg} / \mathrm{m}^{3}\right)$. This allowed us to make comparative study of chloride migration coefficients of concrete mixtures. Compositions of tested concrete mixes are given in Table 6. Amount of air entraining agent in the aerated mixtures was related to the mass of cement $(0.35 \mathrm{~m} \%)$. The consistency was kept at F5 [31] (according to its consistency, fresh concrete is subdivided into stiff (F1), plastic (F2), soft (F3), very soft (F4), free-flowing 


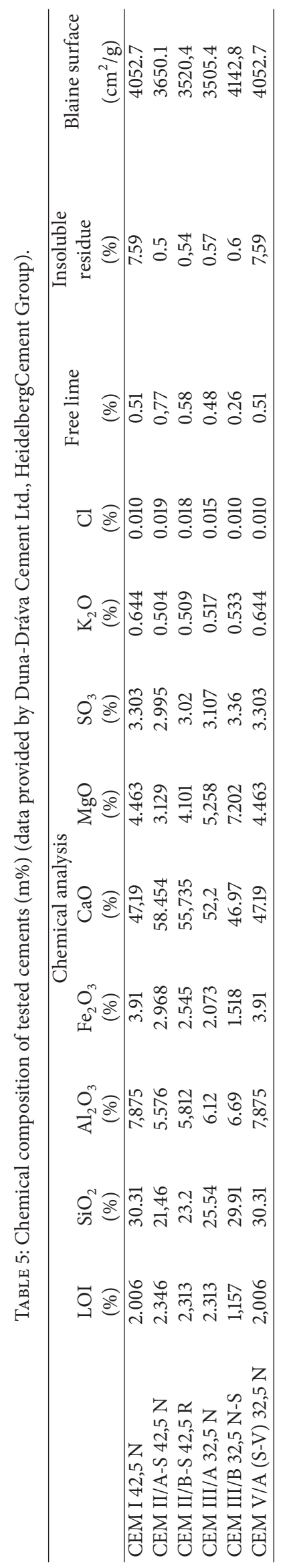


TABLE 6: Compositions of tested concrete mixes with water to cement ratios of $0.35,0.45$, and 0.55 , with (AE) or without (NAE) air entraining agent.

\begin{tabular}{|c|c|c|c|c|c|c|}
\hline \multirow[b]{2}{*}{ Mixture } & \multicolumn{2}{|c|}{$w / c=0.35$} & \multicolumn{2}{|c|}{$w / c=0.45$} & \multicolumn{2}{|c|}{$w / c=0.55$} \\
\hline & $\begin{array}{c}\text { NAE } \\
\left(\mathrm{kg} / \mathrm{m}^{3}\right)\end{array}$ & $\begin{array}{c}\mathrm{AE} \\
\left(\mathrm{kg} / \mathrm{m}^{3}\right)\end{array}$ & $\begin{array}{c}\text { NAE } \\
\left(\mathrm{kg} / \mathrm{m}^{3}\right)\end{array}$ & $\begin{array}{c}\mathrm{AE} \\
\left(\mathrm{kg} / \mathrm{m}^{3}\right)\end{array}$ & $\begin{array}{c}\text { NAE } \\
\left(\mathrm{kg} / \mathrm{m}^{3}\right)\end{array}$ & $\begin{array}{c}\mathrm{AE} \\
\left(\mathrm{kg} / \mathrm{m}^{3}\right)\end{array}$ \\
\hline Cement & 440 & 440 & 440 & 440 & 440 & 440 \\
\hline $\begin{array}{l}\text { water } \\
(w / c=0.35)\end{array}$ & 154 & 154 & 198 & 198 & 242 & 242 \\
\hline $\begin{array}{l}\text { River sand } \\
0-1 \mathrm{~mm}(25 \mathrm{~m} \%)\end{array}$ & 451 & 451 & 425 & 424 & 408 & 396 \\
\hline $\begin{array}{l}\text { River sand } \\
0-4 \mathrm{~mm} \\
(20 \mathrm{~m} \%)\end{array}$ & 361 & 361 & 340 & 339 & 327 & 317 \\
\hline $\begin{array}{l}\text { River gravel } \\
4-8 \mathrm{~mm} \\
(55 \mathrm{~m} \%)\end{array}$ & 993 & 993 & 934 & 932 & 898 & 871 \\
\hline $\begin{array}{l}\text { Superplasticizer } \\
(1.15 \mathrm{~m} \%)\end{array}$ & 5.06 & 5.06 & 1.76 & 1.76 & 0 & 0 \\
\hline $\operatorname{AE}(0.35 \mathrm{~m} \%)$ & - & 1.54 & - & 1.54 & - & 1.54 \\
\hline Sum & 2404.06 & 2405.60 & 2338.76 & 2336.30 & 2315.00 & 2267.54 \\
\hline
\end{tabular}

(F5), and very free-flowing (F6) (EN 12350-5:2009 testing fresh concrete. Flow table test)).

3.2.3. Test Methods. The chloride resistivity was tested by the CTH, rapid electrical, test method described by Tang and Nilsson [32]. The non-steady-state migration coefficient $\left(D_{\text {nssm }}\right)$ was determined on water treated concrete specimens. The specimens were kept in water bath until the age of testing. Then the specimens were cut into discs at the age of 27 days. The test started at the age of 28 days. Test duration was uniformly 8 hours and the applied DC was $30 \mathrm{~V}$. The chloride penetration depths were determined by colorimetric method with application of $0.1 \mathrm{n} \mathrm{AgNO}_{3}$ solution on the split specimens. $D_{\text {nssm }}$ was calculated from the test parameters and variables $[33,34]$. The results of the rapid electric migration test are also known as $D_{\mathrm{RCM}, 28}$. After the determination of the average chloride penetration depths, the discs were ground $\mathrm{mm}$ by $\mathrm{mm}$ with the use of profile grinder. Dry powder samples of the layers were collected to the further analysis. Wet analytical method (Mohr method) was used to determine the total chloride contents of the ground layers.

3.3. Results and Discussion. The non-steady-state migration coefficients $\left(D_{\text {nssm }}\right)$ of the studied concrete mixtures are shown in Figures 4-9.

In Figure 10 typical test results of chloride profiles are shown (example obtained from concrete samples made of CEM II/A 42,5 N Portland-slag cement) with different water to cement ratios, with or without air entraining agents. Test results indicated that chloride concentration in concrete is higher by using air entraining agents considering the same water to cement ratio and the same depth. Another important observation is the higher the water to cement ratio of the concrete specimen, the higher the total chloride concentration in the same depth.
Based on the test results the following observations can be done:

(i) Increase in water to cement ratio results in increase in depth of chloride penetration considering the same cement.

(ii) Chloride penetration depths decrease by increase in slag content of cements considering the same water to cement ratio.

(iii) Observed depths of chloride penetration and those of chloride migration coefficients $\left(D_{\text {nssm }}\right)$ resulted in the following sequence of efficiency for our tested cements (from the best): CEM III/B 32,5 N > CEM V/A (S-V) 32,5 N > CEM III/A 32,5 N > CEM II/B-S 42,5 R > CEM II/A-S 42,5 N > CEM I 42,5 N.

(iv) Chloride penetration depths decrease by increasing the slag content of cement.

(v) Chloride migration coefficients are lower for blended cements compared to CEM I 42,5 N ordinary Portland cement.

(vi) Chloride concentration in concrete is higher by using air entraining agents considering the same water to cement ratio and at the same depth.

(vii) Our experimental results indicated the lowest chloride diffusion coefficient, hence the highest chloride resistivity for concrete of cement CEM III/B 32,5 N among our tested cements.

\section{Conclusions}

In order to support durability design present study concentrated on control of chlorides in concrete. Results of two series of extensive experimental studies are presented concerning (i) chloride binding and (ii) chloride penetration influenced 


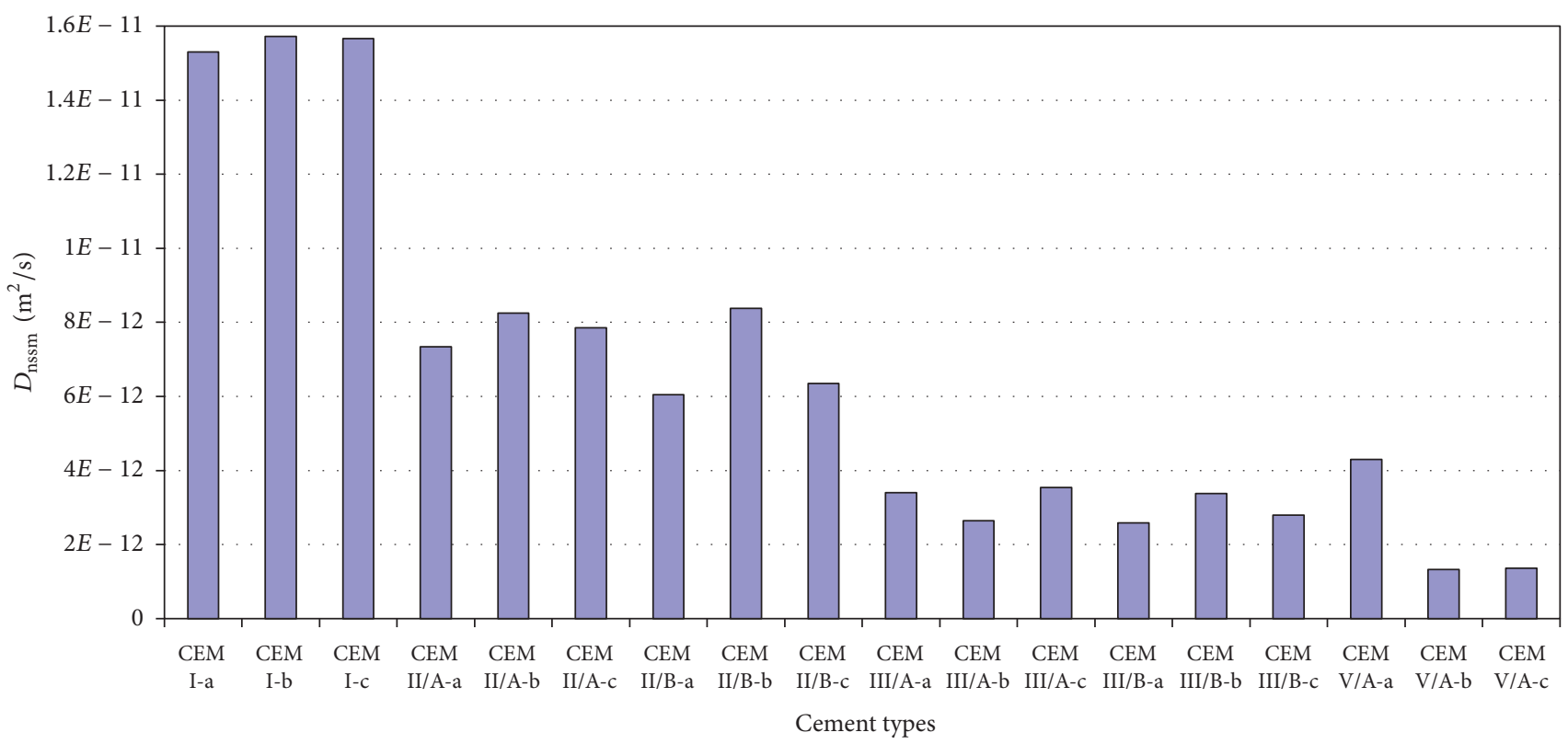

FIGURE 4: Non-steady-state migration coefficients $\left(D_{\text {nssm }}\right)$ of the studied concrete mixtures as a function of cement types, water to cement ratio of 0.35 , and concrete mixtures made with air entraining agents.

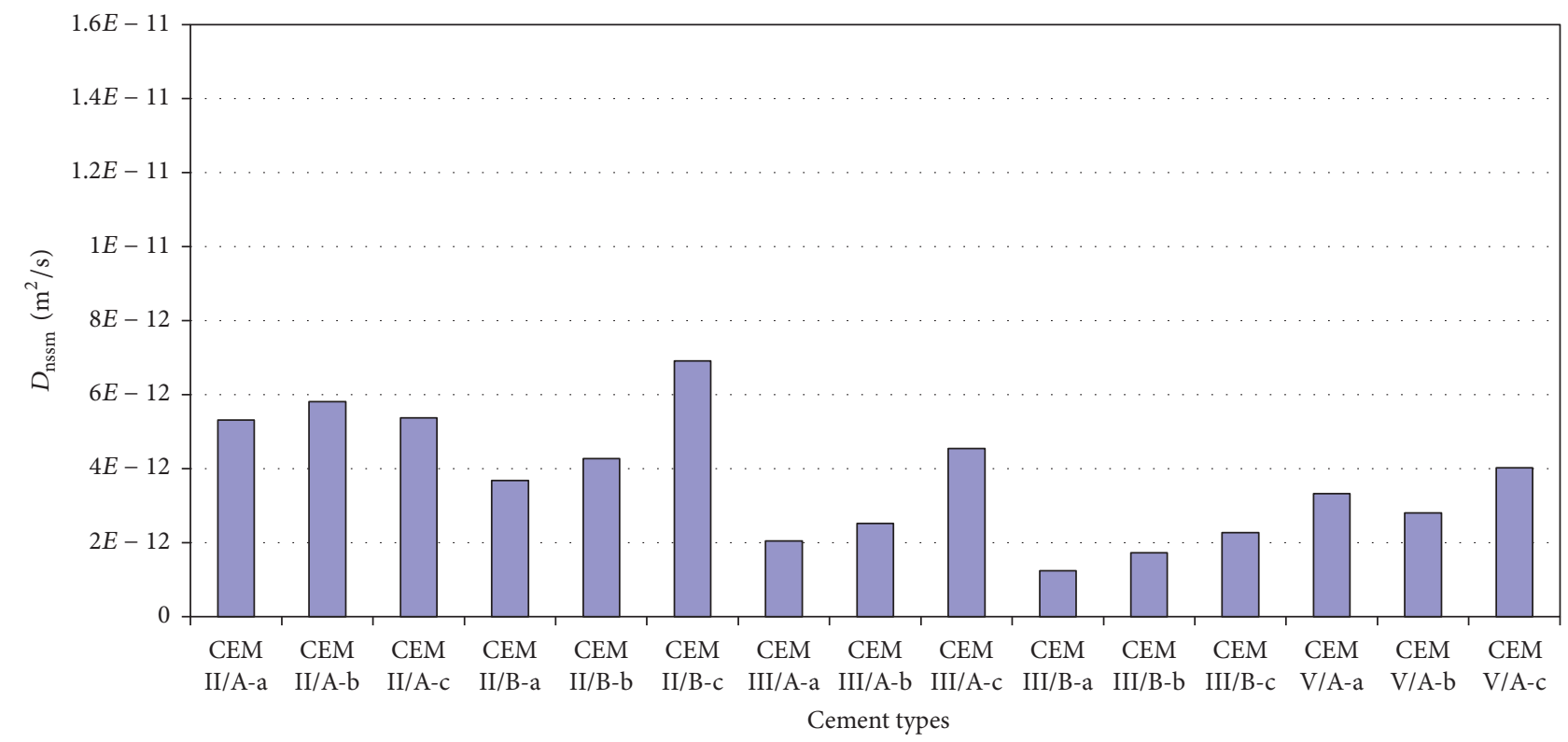

Figure 5: Non-steady-state migration coefficients $\left(D_{\text {nssm }}\right)$ of the studied concrete mixtures as a function of cement types, water to cement ratio of 0.35 , and concrete mixtures made without air entraining agents.

by type of binary or ternary blended cements. The chloride binding capacities of the different cements were studied on cement paste specimens while the non-steady-state migration coefficients were tested on high-strength concrete, with or without application of air entraining agent for different water to cement ratios. Test methods to determine chloride binding capacities included X-ray powder diffraction (XRD) and thermal analyses (TG/DTG/DTA). Results of chloride binding is obtained from the thermogravimetric (TG) mass loss of the second dehydration step of Friedel's salt (TG). Test method to determine the chloride resistivity of concrete was rapid chloride migration test (CTH-test).

\section{(i) Chloride Binding}

(1) Cements with increasing slag contents have improving capacity for chloride binding. In our experiments the chemically bound chloride content increased with the increasing GGBS replacement level in case of slag cements. 


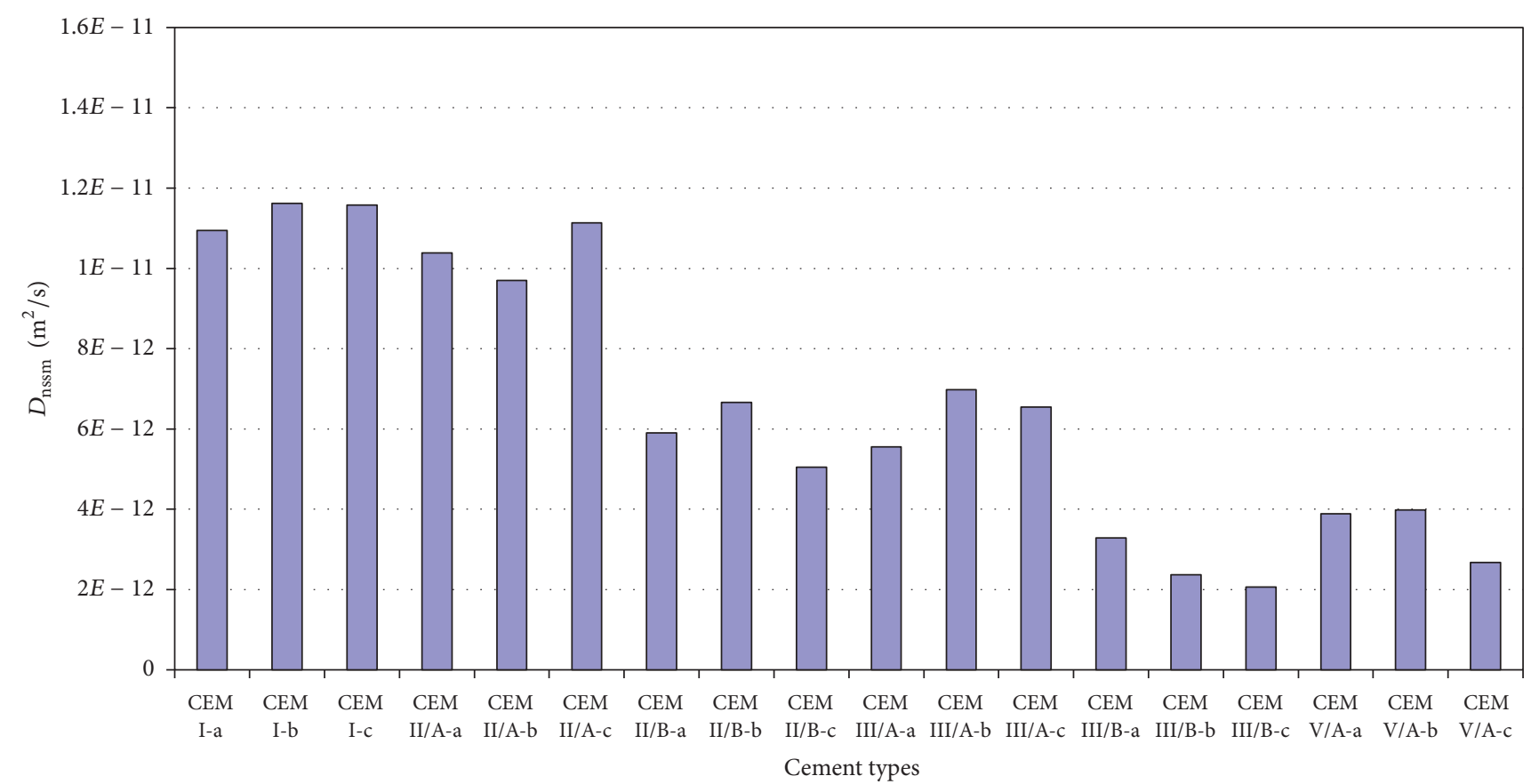

FIGURE 6: Non-steady-state migration coefficients $\left(D_{\text {nssm }}\right)$ of the studied concrete mixtures as a function of cement types, water to cement ratio of 0.45 , and concrete mixtures made with air entraining agents.

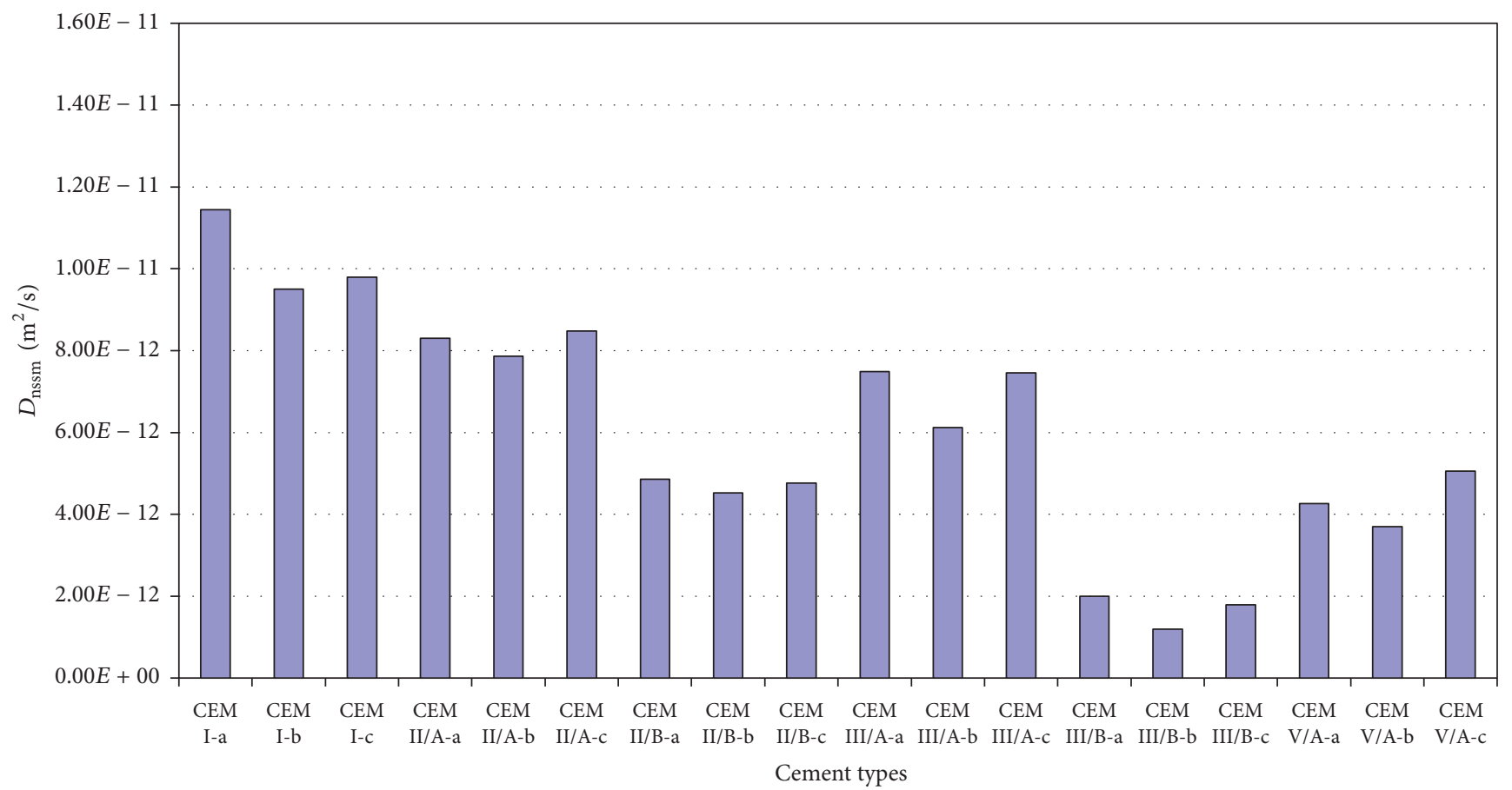

FIGURE 7: Non-steady-state migration coefficients $\left(D_{\text {nssm }}\right)$ of the studied concrete mixtures as a function of cement types, water to cement ratio of 0.45 , concrete mixtures made without air entraining agents.

(2) It was also experimentally shown that in the same type of cement (CEM II/B) the addition of ground granulated blast furnace slag (in Portland-slag cement, CEM II/B 32,5 R) is more effective in chloride ion binding than in Portland composite cement with fly ash and limestone (CEM II/B-M (V-L) 32,5 R).
Limestone acts as an inert material for chloride binding.

(3) During steam curing AFm aluminate hydrates also formed in addition to AFt phase (ettringite). Formation of monosulphate is accelerated by the higher temperature of steam curing. Higher amounts of 


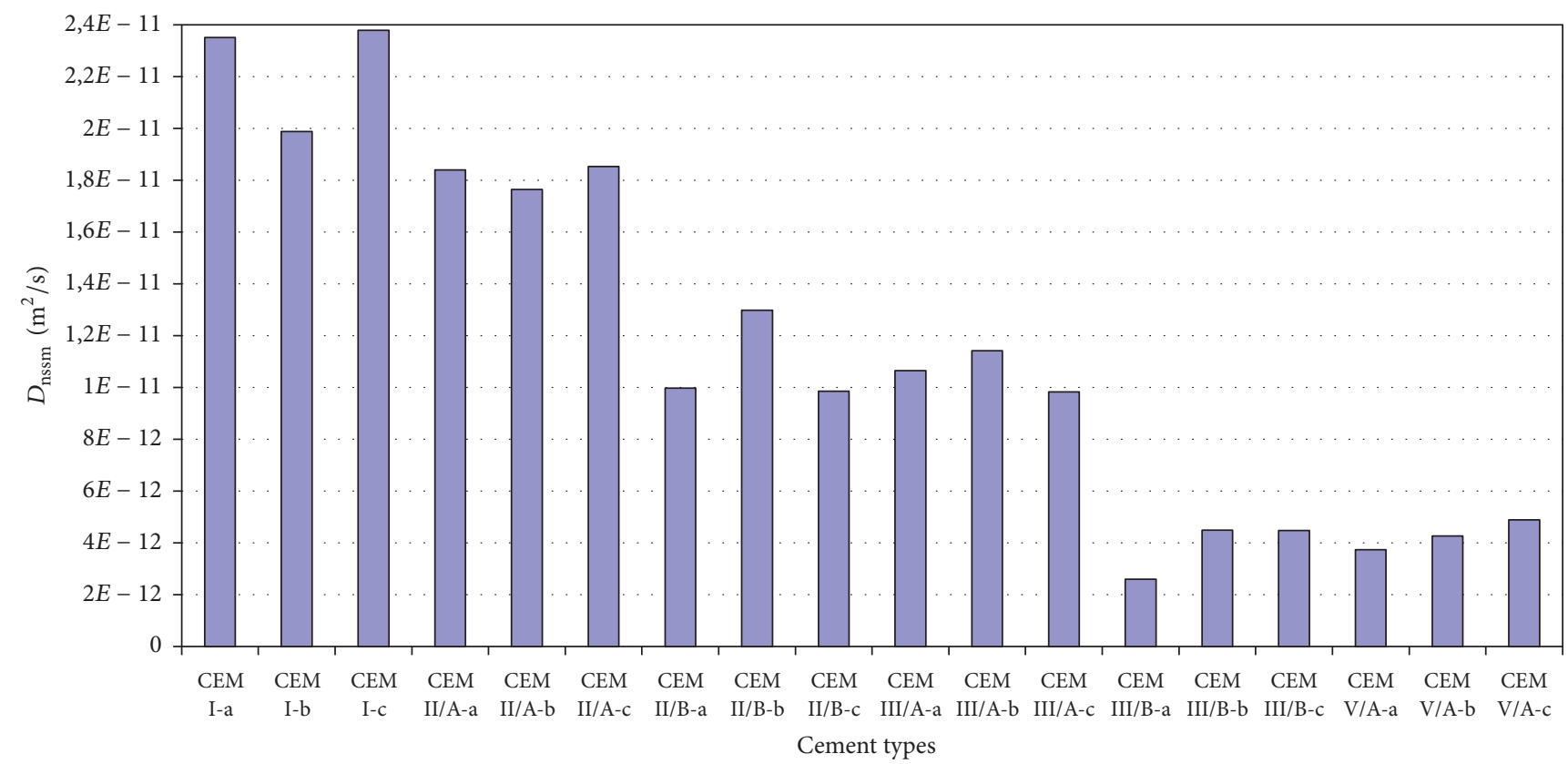

FIGURE 8: Non-steady-state migration coefficients $\left(D_{\text {nssm }}\right)$ of the studied concrete mixtures as a function of cement types, water to cement ratio of 0.55 , and concrete mixtures made with air entraining agents.

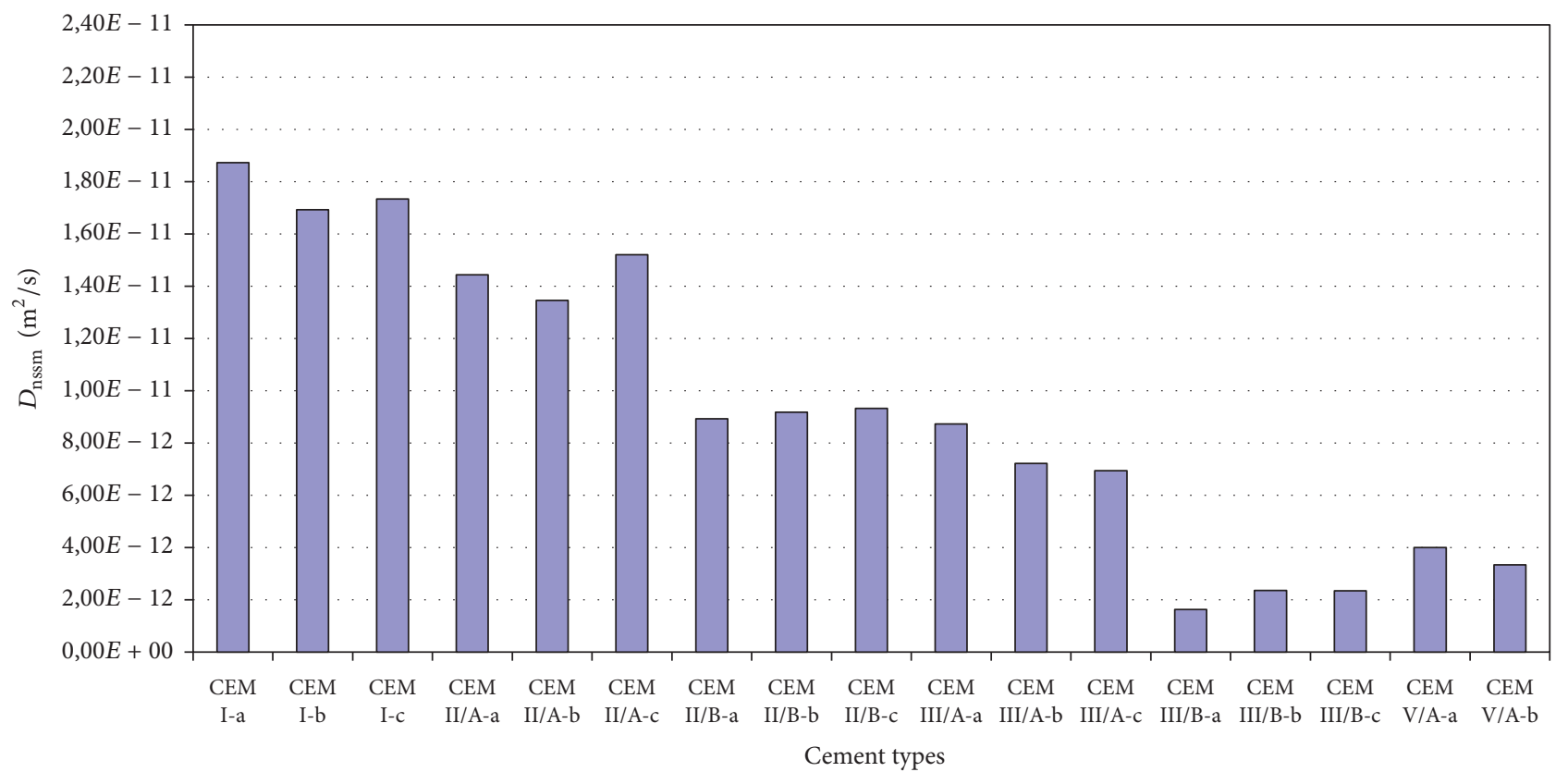

FIGURE 9: Non-steady-state migration coefficients $\left(D_{\text {nssm }}\right)$ of the studied concrete mixtures as a function of cement types, water to cement ratio of 0.55 , and concrete mixtures made without air entraining agents.

monosulphate are available in steam-cured cement paste samples compared to non-steam-cured samples. In presence of chloride ions, sulphate ions released by the chloride binding promote the formation of the secondary ettringite. Steam curing (used for precast elements) contributes to improved chloride binding of cements.

(4) The chloride ion binding capacities of cements improved by the age of samples. (ii) Chloride Resistivity. Test results indicated that the increasing substitution of clinkers by GGBS improves the chloride resistivity in concrete made with the same water to cement ratio. The application of air entraining agent increases the values of $D_{\text {nssm }}$ (reducing the chloride resistivity), because the permeability increases by the increased porosity.

(5) Chloride migration coefficients decrease with increase in slag content of cements; chloride penetration depths decrease as well by increase in slag content 


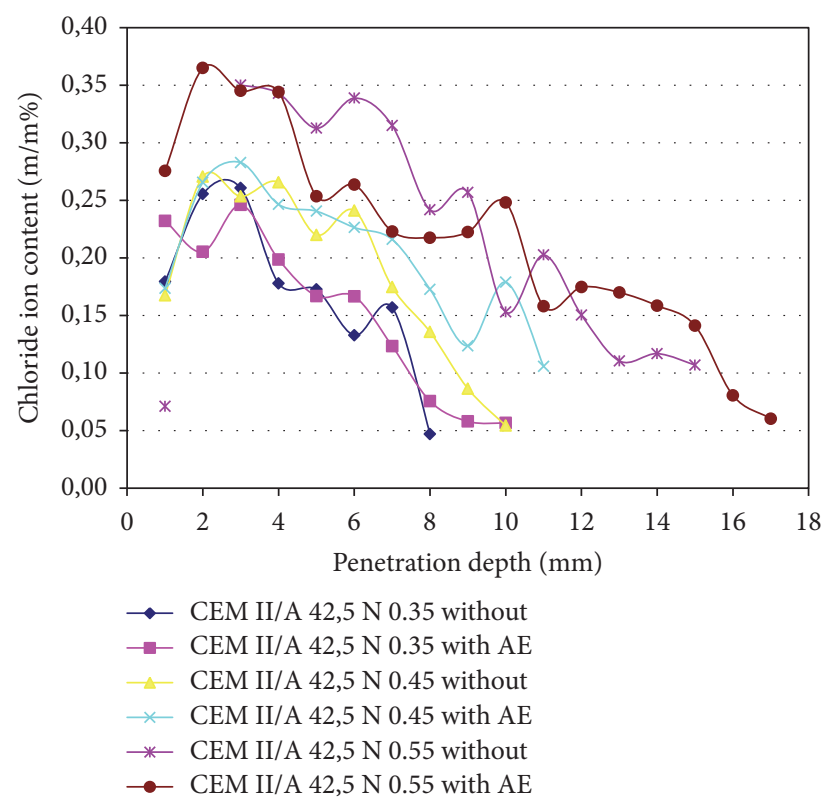

Figure 10: Chloride profiles with Portland-slag cement CEM II/A$\mathrm{S} 42,5 \mathrm{~N}$ with different water to cement ratios, with or without air entraining agents.

of cements considering the same water to cement ratio.

(6) Application of air entrainment negatively influences the chloride migration coefficients; that is, chloride penetration depths are increasing in case of air entrained concrete.

(7) Chloride concentration in concrete is higher by using air entraining agents considering the same water to cement ratio and the same depth of specimens.

(8) Observed depths of chloride penetration and those of chloride migration coefficients resulted in the following sequence of efficiency for the tested cements (from the best): CEM III/B 32,5 N > CEM V/A (S-V) $32,5 \mathrm{~N}>$ CEM III/A 32,5 N > CEM II/B-S 42,5 R > CEM II/A-S 42,5 N > CEM I 42,5 N.

(9) Our experimental results indicated the lowest chloride migration coefficient, hence the highest chloride resistivity for cement CEM III/B 32,5 $\mathrm{N}$ among our tested cements.

Our observations give guidance to durability evaluations as well as mix design of concrete.

\section{Conflicts of Interest}

The authors declare that there are no conflicts of interest regarding the publication of this article.

\section{Acknowledgments}

The authors acknowledge the support by the Hungarian Research Grant NVKP_16-1-0019 "Development of Concrete
Products with Improved Resistance to Chemical Corrosion, Fire or Freeze-Thaw.”

\section{References}

[1] L-O. Nilsson, Prediction Models for Chloride Ingress And Corrosion Initiation in Concrete Structures, Chalmers University of Technology, 2001.

[2] K. Tuutti, "Corrosion of steel in concrete," CBI Research Report 4:82, Swedish Cement and Concrete Research Institute, Stockholm, Sweden, 1982.

[3] O. A. Kayyali and M. N. Haque, " $\mathrm{Cl}^{-} / \mathrm{OH}^{-}$ratio in chloridecontaminated concrete - a most important criterion," Magazine of Concrete Research, vol. 47, no. 172, pp. 235-242, 1995.

[4] J. M. Frederiksen, L-O. Nilsson, E. Poulsen, P. Tang L, and A. Andersen, "HETEK, a system for estimation of chloride ingress into concrete, theoretical background. the danish road directorate," The Danish Road Directorate 83, HETEK, 1997.

[5] C. Alonso, C. Andrade, M. Castellote, and P. Castro, "Chloride threshold values to depassivate reinforcing bars embedded in a standardized OPC mortar," Cement and Concrete Research, vol. 30, no. 7, pp. 1047-1055, 2000.

[6] A. Neville, "Chloride attack of reinforced concrete: an overview," Materials and Structures, vol. 28, no. 2, pp. 63-70, 1995.

[7] S. Matthews, Design of Durable Concrete Structures, vol. ISBN13:978-1848061750, IHS BRE Press, 2014.

[8] fib, "Model Code for Concrete Structures," Wiley, 2010.

[9] fib, "Benchmarking of deemed-to-satisfy provisions in standards," fib Bulletin 76 ISBN 978-2-88394-116-8, Lausanne, Switzerland, 2016.

[10] P. M. Friedel, "Sur un chloro-aluminate de calcium hydraté se maclant par compression," Bulletin de la Société Française de Minéralogie, vol. 19, pp. 122-136, 1897.

[11] M. V. A. Florea and H. J. H. Brouwers, "Chloride binding related to hydration products: Part I: Ordinary Portland Cement," Cement and Concrete Research, vol. 42, no. 2, pp. 282-290, 2012.

[12] K. Larsen, Chloride binding in concrete-effect of surrounding environment and concrete composition [Ph.D. thesis], The Norwegian University of Science and Technology, 1998.

[13] J. J. Beaudoin, V. S. Ramachandran, and R. F. Feldman, "Interaction of chloride and CSH," Cement and Concrete Research, vol. 20, no. 6, pp. 875-883, 1990.

[14] S. Nagataki, N. Otsuki, T.-H. Wee, and K. Nakashita, "Condensation of chloride ion in hardened cement matrix materials and on embedded steel bars," ACI Materials Journal, vol. 90, no. 4, pp. 323-332, 1993.

[15] O. Wowra and M. J. Setzer, "About the interaction of chloride and hardened cement paste," in Proceedings of the Proceedings of 2nd International RILEM Workshop "Testing and Modelling Chloride Ingress into Concrete”, C. Andrade and J. Kropp, Eds., pp. 3-12, Paris, France, 2000.

[16] A. K. Suryavanshi, J. D. Scantlebury, and S. B. Lyon, "Mechanism of Friedel's salt formation in cements rich in tri-calcium aluminate," Cement and Concrete Research, vol. 26, no. 5, pp. 717-727, 1996.

[17] H. Zibara, Binding of external chloride by cement pastes [Ph.D. thesis], University of Toronto, Department of Building Materials, 2001 .

[18] F. P. Glasser, A. Kindness, and S. A. Stronach, "Stability and solubility relationships in AFm phases: part I. chloride, sulfate 
and hydroxide," Cement and Concrete Research, vol. 29, no. 6, pp. 861-866, 1999.

[19] H. Justnes, "A review of chloride binding in cementitious systemes," Nordic Concrete Research, vol. 21, pp. 1-6, 1996.

[20] M. Balonis, B. Lothenbach, G. Le Saout, and F. P. Glasser, "Impact of chloride on the mineralogy of hydrated portland cement systems," Cement and Concrete Research, vol. 40, no. 7, pp. 1009-1022, 2010.

[21] K. Kopecskó, Chloride ion binding capacity of clinker minerals and cements influenced by steam curing [Ph.D. thesis], in Hungarian, Budapest University of Technology and Economics, 2006.

[22] J. Hill and J. H. Sharp, "The mineralogy and microstructure of three composite cements with high replacement levels," Cement and Concrete Composites, vol. 24, no. 2, pp. 191-199, 2002.

[23] R. D. Hooton and M. P. Titherington, "Chloride resistance of high-performance concretes subjected to accelerated curing," Cement and Concrete Research, vol. 34, no. 9, pp. 1561-1567, 2004.

[24] R. K. Dhir, M. A. K. El-Mohr, and T. D. Dyer, "Chloride binding in GGBS concrete," Cement and Concrete Research, vol. 26, no. 12, pp. 1767-1773, 1996.

[25] R. Luo, Y. Cai, C. Wang, and X. Huang, "Study of chloride binding and diffusion in GGBS concrete," Cement and Concrete Research, vol. 33, no. 1, pp. 1-7, 2003.

[26] K. Kopecskó, "Presence of chloride ions in concrete. MÜSZAKI SZEMLE (Technical Review)," Hungarian Technical Scientific Society of Transylvania, 2009.

[27] "Cement composition, specifications and conformity criteria for common cements," MSZ EN 197-1:2000.

[28] "Methods of testing cement. Determination of setting times and soundness," MSZ EN 196-3:2005.

[29] H. J. Kuzel, "Röntgenuntersuchung im System $3 \mathrm{CaO} \cdot \mathrm{Al}_{2} \mathrm{O}_{3}$ - $\mathrm{CaSO}_{4} \cdot \mathrm{nH}_{2} \mathrm{O}-3 \mathrm{CaO} \cdot \mathrm{Al}_{2} \mathrm{O}_{3} \cdot \mathrm{CaCl}_{2} \cdot \mathrm{nH}_{2} \mathrm{O}-\mathrm{H}_{2} \mathrm{O}$ '”' Neues Jahrbuch Mineralog. Monatsh, pp. 193-200, 1966.

[30] H. F. W. Taylor, Cement Chemistry, Academic Press, New York, NY, USA, 1990.

[31] “Testing fresh concrete. Flow table test," MSZ EN 12350-5:2009.

[32] L. Tang and L. O. Nilsson, "Chloride diffusivity in high strength concrete," Nordic Concrete Research, vol. 11, pp. 162-170, 1992.

[33] T. Luping, L. Nilsson, and P. Basheer, Resistance of Concrete to Chloride Ingress: Testing and Modelling, ISBN: 978-0-203-882412, CRC Press, 2011.

[34] "NT Build 492," Concrete, mortar and cement-based repair materials: chloride migration coefficient from non-steady-state migration experiments. 

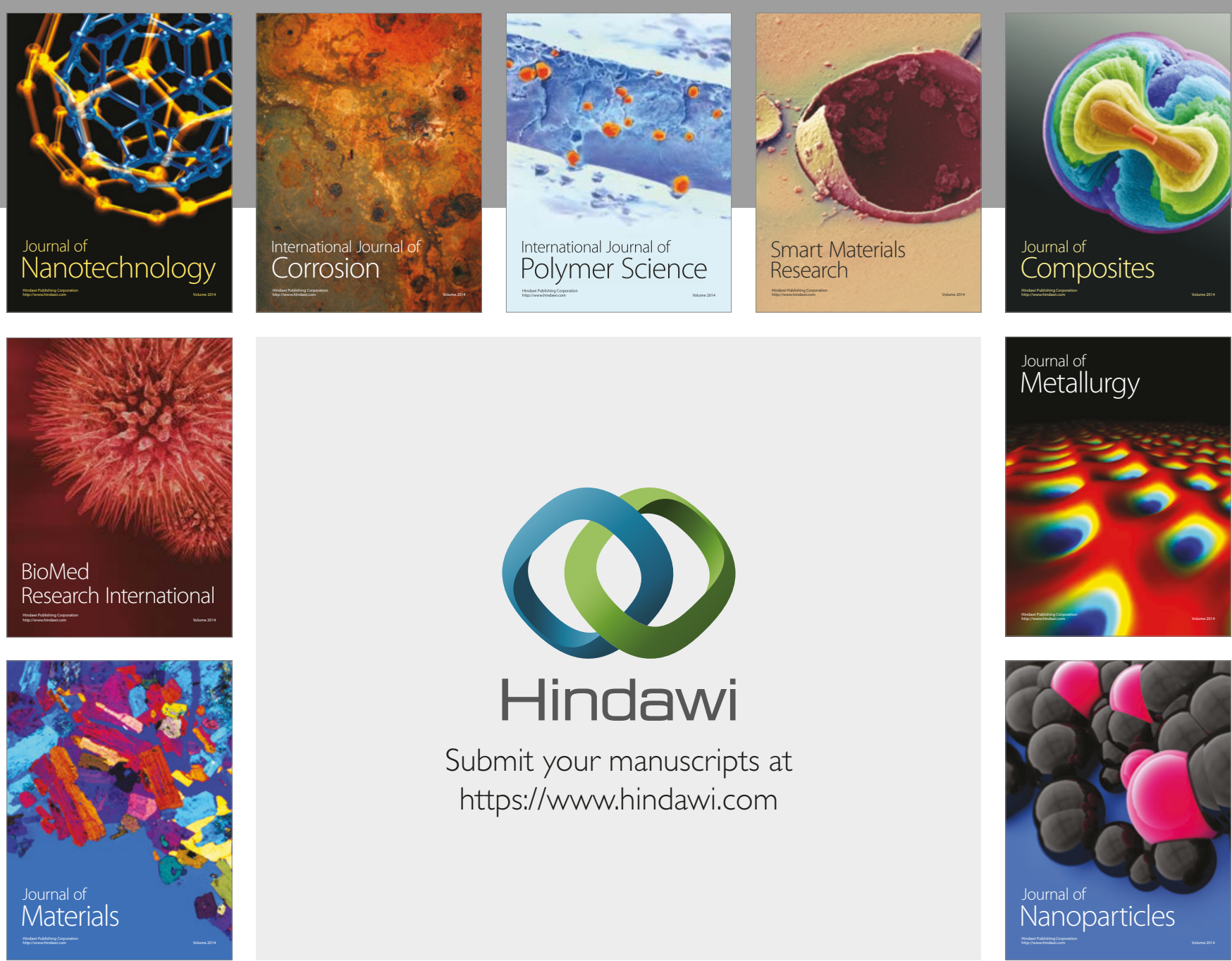

\section{Hindawi}

Submit your manuscripts at

https://www.hindawi.com
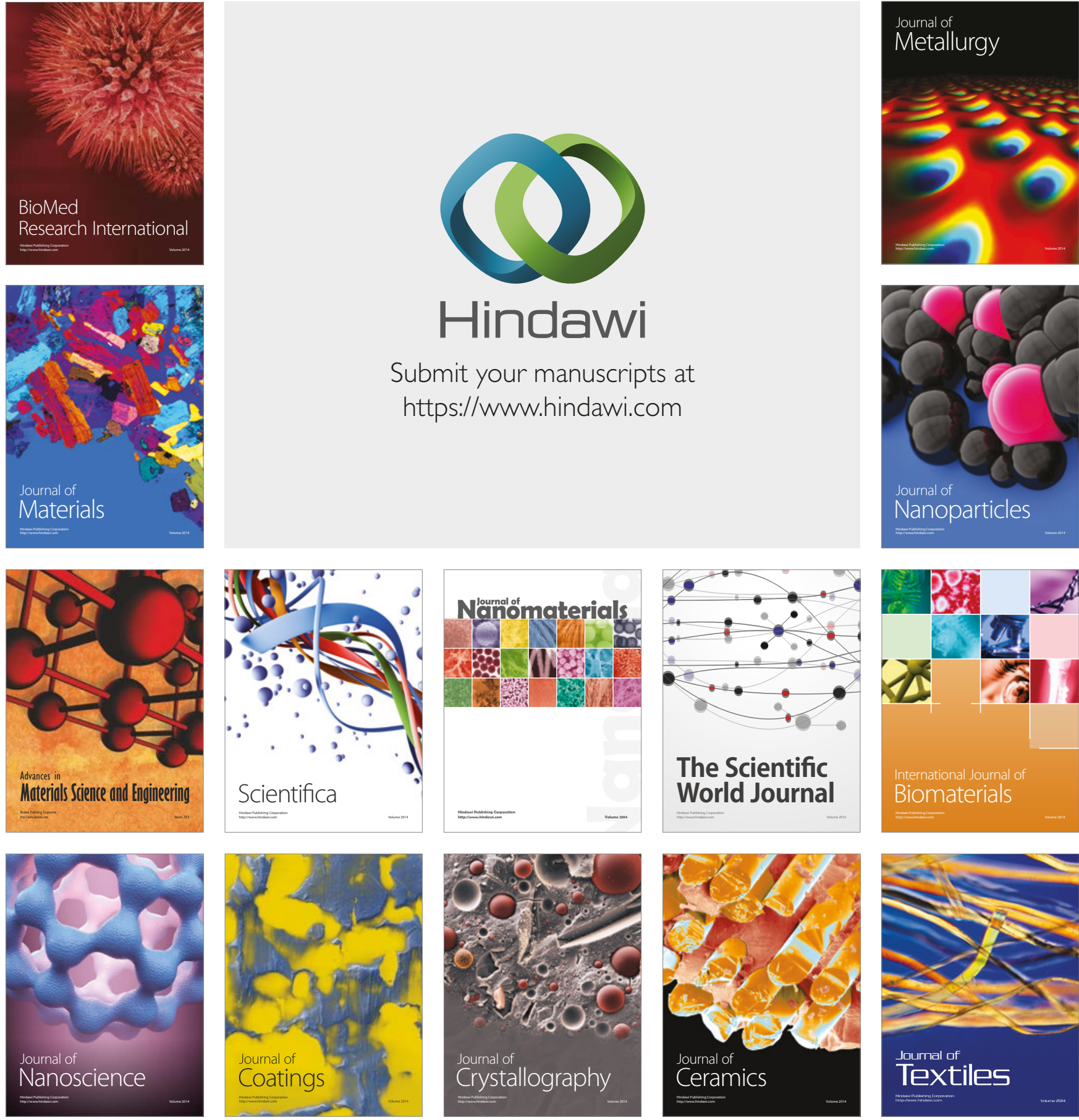

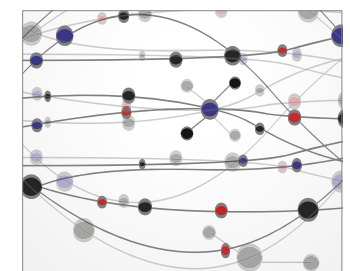

The Scientific World Journal
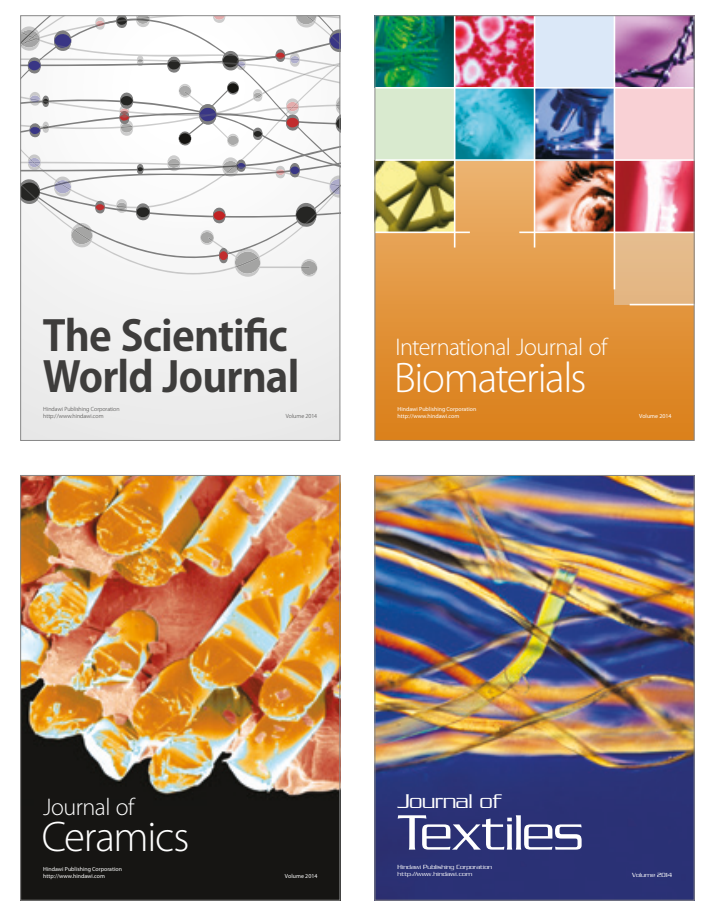